NBER WORKING PAPER SERIES

\title{
WHY ARE SOME PUBLIC OFFICIALS MORE CORRUPT THAN OTHERS?
}

\author{
Jennifer Hunt \\ Working Paper 11595 \\ http://www.nber.org/papers/w11595
}

\author{
NATIONAL BUREAU OF ECONOMIC RESEARCH \\ 1050 Massachusetts Avenue \\ Cambridge, MA 02138 \\ August 2005
}

This paper has been prepared for the Handbook of Economic Corruption, edited by Susan Rose-Ackerman and forthcoming in the Edward Elgar Press. I thank Vincent Chandler for excellent research assistance, and the Social Science and Humanities Research Council of Canada for financial support. I am grateful to Susan Rose-Ackerman, Sonia Laszlo and participants in the McGill summer seminar series for comments, to Miguel Jaramillo Baanante for enlightening conversations about Peru and to the Instituto Nacional de Estadística e Información for providing the data. I am also affiliated with the CEPR, the IZA and the DIW-Berlin. The views expressed herein are those of the author(s) and do not necessarily reflect the views of the National Bureau of Economic Research.

(O2005 by Jennifer Hunt. All rights reserved. Short sections of text, not to exceed two paragraphs, may be quoted without explicit permission provided that full credit, including $\odot$ notice, is given to the source. 
Why Are Some Public Officials more Corrupt Than Others?

Jennifer Hunt

NBER Working Paper No. 11595

August 2005

JEL No. K4, H4

\begin{abstract}
$\underline{\text { ABSTRACT }}$
Using detailed Peruvian data measuring bribery, I assess which types of public official are most corrupt and why. I distinguish between the bribery rate and the size of bribes received, and seek to explain the variation in each across public institutions. The characteristics of officials' clients explain most of the variation for bribery rates, but none for bribe amounts. A measure of the speed of honest service at the institution explains much of the remaining variation for both bribery rates and amounts. The results indicate that the bribery rate is higher at institutions with bribe-prone clients, and that bribery rates and bribe amounts are higher where clients are frustrated at slow service. Faster and better service would reduce corruption. Overall, the judiciary and the police are by far the most corrupt institutions.
\end{abstract}

Jennifer Hunt

Department of Economics

McGill University

855 Sherbrooke Street West

Montreal, QC H3A 2T7

CANADA

and NBER

jennifer.hunt@mcgill.ca 
In all countries, some public officials are more corrupt than others depending upon variations in the opportunities for private gain and the willingness to pay of private citizens and businesses. Effective anti-corruption campaigns need to be able both to identify which types of officials are most likely to be corrupt and to understand why some, such as the judiciary or the police, are more corrupt than others. A number of surveys report household and business perceptions of corruption across official types, but these data provide no information on why one type of official is more susceptible to corruption than another. One is left with plausible, but empirically untested, theoretical speculations. Newly available Peruvian data permit analysis of this very important issue. In this paper I use the data both to measure corruption by type of official and to seek the causes of corruption across official types.

The existing literature has uncovered some determinants of corruption using a crosssection of countries. Factors found to be associated with lower corruption include a common law legal system, Protestant traditions and British colonial rule (Treisman 2000), fiscal decentralization (Fisman and Gatti 2000), higher relative salaries for public officials (van Rijckeghem and Weder 2001), the absence of an industrial policy (Ades and Di Tella 1997) and a greater presence of women in parliament and the civil service (Swamy et al. 2001). Most of these causes vary only at the country level and most are not amenable to direct policy interventions. My data allow me to study determinants of corruption whose natural variation is across official types; this gives new insights into the causes of corruption and generates some practical policy implications. ${ }^{1}$

\footnotetext{
${ }^{1}$ The World Bank has conducted surveys of public officials in several countries, and qualitative responses related to corruption are available at www1.worldbank.org/prem/acr/bankproj.html. Peru is not one of the countries surveyed.
} 
My data are from the national household survey of Peru, a middle-ranking country in Transparency International's Corruption Perceptions Index (Transparency International 2004). Concern about corruption led the Peruvian statistical agency to include a detailed module on bribery in the 2002 and 2003 household surveys, measuring usage rates and reports of bribery for twenty-one types of public official. The questions pertain to the previous twelve months, and the official types are specific Peruvian institutions, such as the judiciary or the social security agency (political parties and the legislature are not among the specified types). Thus the emphasis is on reports of actual experience, not perceptions, of corruption. ${ }^{2}$

To establish a corruption ranking by official type, I calculate the ratio of an institution's share of bribe takings to its share of household/official interactions. This measure corrects for the fact that an institution might appear to be relatively honest simply because few households even interact with officials from that institution. By this measure, the judiciary is by far the most corrupt official type in Peru, with an impressive 42 per cent of reported bribe revenues compared to only 2 per cent of interactions. The police force is the other extremely corrupt institution, with 27 per cent of bribes and only 2 per cent of interactions (see Table 1 below). Transparency International (2004) reports that in 36 of 62 countries surveyed, respondents perceived the police and the judiciary to be the most corrupt institutions after political parties and the legislature. This indicates that the Peruvian situation is not unique and could provide lessons for other countries.

There are a number of reasons why corruption might vary across official types. First, the services offered may be demanded by clients with different ability and willingness to pay or even

\footnotetext{
${ }^{2}$ The few previous papers using measured corruption include Hunt (2004), Hunt and Laszlo (2005), Mocan (2004), Svensson (2003) and some analysis in Swamy et al. (2001). Di Tella and Schargrodsky (2003) convincingly infer corruption from their data.
} 
different scruples. Officials have some monopoly power and can charge different prices (including zero) to different clients for their services (price-discrimination). We would expect officials in institutions with richer clients to take bribes more frequently and to take larger bribes. Jennifer Hunt and Sonia Laszlo (2005) have confirmed empirically that richer clients do pay more frequent and higher bribes, both in general and within official type.

Second, officials provide different types of services in return for bribes, and these vary in value. This influences the client's willingness to bribe as well as the level of payoffs. Bribes vary in size both because the value of the ultimate benefit varies and because officials' ability to provide the benefit promptly also varies. The latter, in turn, depends on three considerations: how many officials are involved in the conclusion of business for one client, how easy it is for superiors to monitor officials, and the resources available to the institution compared to the demands on its officials. For example, police officers, who often meet clients one-on-one in the street, have complete control over the imposition of fines and are hard to monitor. If the resources of the agency granting drivers' licenses are insufficient to prevent large queues forming, the conditions will be ripe for frustrated clients to bribe to get to the head of the queue. ${ }^{3}$

Third, institutions vary in the degree of internal competition between officials with different levels of scruples. For example, a customer wishing to have a telephone connected who encounters an official demanding a bribe could return the next day and hope for an official with more scruples. By contrast, in a court case brought before a judge, it will usually be impossible to choose another judge unless he or she is caught explicitly demanding a payoff. ${ }^{4}$ Fourth,

\footnotetext{
${ }^{3}$ Bardhan (1997) discusses how giving many officials the power to stop a file may backfire as a means of reducing bribery if the client ends up bribing all the officials. Rose-Ackerman (1978) and Lui (1985) analyze bribery and queuing.

${ }^{4}$ Rose-Ackerman (1978: chapter 8, 1999: chapter 4) and Shleifer and Vishny (1993) discuss the significance of competition between officials.
} 
institutions may vary in the degree to which combating corruption is a management priority. Finally, public officials with few scruples will migrate to institutions which offer more opportunities for corruption, reinforcing other patterns.

The Peruvian data permit me to quantify the impact of three factors: the direct effect of client characteristics, the indirect effect of client characteristics, and the share of client cases that officials acting honestly are able to conclude within the twelve-month window, adjusted for client characteristics (the "adjusted conclusion rate"). The direct impact of client characteristics indicates whether the price-discrimination model helps to explain cross-official corruption. Client scruples are, of course, unobservable, so their impact cannot be judged. I assess the indirect or spillover effects of the client characteristics by asking if the characteristics of the average client who deals with a given official type has an impact on corruption even after household characteristics are taken into account. This captures whether official/client interactions are influenced by the characteristics of other clients. This could happen if rich clients corrupt officials so they behave less scrupulously with all clients, or if rich clients attract unscrupulous officials to the institution. The adjusted conclusion rate is designed to capture administrative efficiency, resources and lack of red tape.

Raw bribery rates across official types range from almost zero to 37 per cent, and client characteristics explain 85 per cent of the variance in these rates. Nevertheless, even after correcting for differences in client characteristics, adjusted bribery rates still span 15 percentage points. Fully 46 per cent of this variance is explained by the adjusted conclusion rate: a 10 percentage point increase in this rate (a standard deviation) reduces the adjusted bribery rate by 4-5 percentage points, a very large effect. This is a causal effect as long as the conclusion rate of officials acting honestly is not affected by the extent of bribery in their institution. The results 
indicate that bribery rates are higher at institutions whose clients have a bribe-prone profile and whose clients are frustrated with slow service. Policy priorities for reducing the bribery rate should be improving administrative efficiency, providing more resources and cutting red tape.

The data reveal that neither raw bribery rates and bribe amounts nor rates and amounts adjusted for client characteristics are closely correlated across official types. Adjusting for client characteristics does not reduce the variance in bribe amounts across official type. However, a 10 percentage point increase in the adjusted conclusion rate reduces the adjusted bribe amount by a significant 30-32 per cent and explains at least 20 per cent of the variance. The results indicate that while differences in client profiles do not help explain the variation in bribe amounts by official type, clients frustrated with slow service pay higher and more frequent bribes.

I find some evidence that there is a role for spillover effects between clients in explaining both bribery rates and average bribe amounts. However, the results differ qualitatively between the bribery rate and bribe amount outcomes, and are difficult to interpret. I draw no firm conclusions.

Most of the high bribery rate for both the police and the judiciary is explained by the higher propensity to bribe (whether voluntarily or not) of their clients. That different clients use different types of official is not something that can or should be changed. However, the relatively high bribery rate of the judiciary, after adjusting for client characteristics, seems to be adequately explained by the judiciary's low conclusion rate ( 54 per cent, compared to 93 per cent for clients in the whole sample). The low conclusion rate also helps explain the very high value of bribes received by the judiciary. A key policy challenge for Peru is to train more lawyers and judges for permanent positions, so as to speed up judicial proceedings without sacrificing quality. The police, in contrast, have a much higher bribery rate, adjusted for observable client characteristics, 
than their conclusion rate would predict. Although increasing the conclusion rate would be helpful, the need for additional measures is even more urgent than for other institutions. These might include attempts to restrict abuse of police monopoly power, for example, by limiting the extortion of bribes from innocent motorists.

\section{Corruption in Peru}

Discoveries leading to the resignation and self-exile of the president, Alberto Fujimori, revealed the enormous scale of grand corruption in Peru. Video-taped evidence showed that Vladimir Montesinos, Fujimori's spy chief, had repeatedly bribed congressmen to defect to Fujimori's party to ensure its majority in Congress. In addition, large bribes had enabled Montesinos to control most of the media and influence the judiciary (McMillan and Zoido 2004).

However, Fujimori is credited with having reduced petty corruption. His 1990-2000 administration pursued policies that reduced the role of government, which he justified not only on efficiency grounds, but on the grounds that reducing the role of government would reduce opportunities for corruption. He attempted to reduce corruption in the police and municipal governments, in the latter case by establishing a supervisory agency to field citizen complaints. However, despite some progress, several institutions with which ordinary people have much contact were judged to suffer from pervasive corruption by Transparency International (TI) in a November 2001 report. $^{5}$

Fujimori's reforms of the judiciary are thought to have been ineffective and may even have made it more corrupt. An increase in the number of temporary judges, appointed in part to help clear backlogs, contributed to corruption. Such judges, representing 74 per cent of all judges, were vulnerable to political pressure and susceptible to corruption because of their lack

\footnotetext{
${ }^{5}$ Most of the rest of this section is based on this report: Transparency International (2001).
} 
of job security. The slowness of judicial proceedings (and, one suspects, the high corruption) has led to the establishment of various arbitration systems for settling disputes (U.S. Department of State 2005).

TI argues that poor pay and equipment reduced the morale of the police, which combined with weak internal controls and sanctions, rendered them susceptible to small- and large-scale corruption, as well as to cooperation with criminals. At the time of its report, TI found that it was customary to bribe the transit police.

Public administration generally was corrupted by poor pay, complex procedures for sanctioning bribe-taking and the frequent overturning of administrative sanctions by the judiciary. Only public servants with contracts comparable to those in the private sector were well-paid, but they lacked the job security that would protect them from political interference (and, presumably, that would allow them to report corruption by superiors).

The interim regime and the presidency of Alejandro Toledo that followed Fujimori's downfall both made corruption a priority, but they focused particularly on prosecuting actors in the Montesinos affair. Nevertheless, a group including representatives of civil society and the World Bank drew up a list of anti-corruption proposals in 2001. Some initiatives put into place include the naming of an "Anti-Corruption Tsar", the establishment of a special anti-corruption police division and the introduction of an anti-nepotism law for the public service. Ominously, however, the Tsar was fired in December 2004 after seeking to investigate accusations of corruption in the Toledo administration. ${ }^{6}$

\footnotetext{
${ }^{6}$ www.signonsandiego.com/news/world/20041217-0702-peru-corruption.html
} 


\section{Data}

The basic data for this study are contained in the 2002 and 2003 waves of the Peruvian household survey, the Encuesta Nacional de Hogares (ENAHO), conducted by the national statistical agency, the Instituto Nacional de Estadística e Información (INEI). The sample includes responses by more than 36000 households to a large number of economic and demographic questions and to questions on the use and bribery of public officials. One respondent per household indicated for each of twenty-one official types and for the previous twelve months whether the household had interacted with the official; whether anyone in the household had paid a bribe or been asked to pay a bribe; if they had paid, how much they had paid, and whether they had concluded their business with the official. The only missing aspect of bribery is the case of the client offering a bribe and the official refusing. The 2002 survey was

conducted in October, November and December 2002, while the "2003" survey was spread evenly across the period May 2003 to April 2004.

Overall, 4.9 per cent of households report having bribed in the previous twelve months.

Of households who had used at least one public official, 5.7 per cent had bribed. Although the share of households bribing may seem low, the bribery rates for some official types are very high, indicating that, at least for some official types, respondents were not ashamed or afraid to admit having bribed. The number of bribery episodes is somewhat understated, however, because each respondent can only report one bribery episode per official per year. If clients commonly use agents to act as intermediaries between themselves and officials, and bribes paid by the agent are reported in the survey by the agent (or no-one), rather than the client, the understatement will be worse and the share of households bribing will also be understated. A 2003 survey by Proética, a Peruvian anti-corruption group, gathered information on bribes and agents ("tramitadores") (Proética 2003). Fifty-two per cent of respondents who had bribed to 
obtain a driver's licence reported having paid the bribe to an agent, while the share was 15 per cent or less for the other nine activities reported in the summary statistics (including dealing with a judge, customs, police on patrol and transit fines). ${ }^{7}$

A 2004 Transparency International survey of 416 respondents in greater Lima found 14 per cent of respondents had bribed in the previous twelve months, compared to 6.0 per cent among the 3758 Lima respondents in my 2002-2003 data. However, the TI question did not restrict itself to bribes paid to public officials. Proética reports much higher bribery rates for the years 2002, 2003 and 2004 of 32 per cent, 29 per cent and 27 per cent, respectively (Proética 2004). Proética's bribery rates, conditional on the use of particular officials, look very similar to mine, but their usage rates look implausibly high for a window of one year. For example, in 2004, 24 per cent report using a judge compared to 2 per cent in my sample; 14 per cent of those who used a judge report having bribed in this connection in the Proética sample, compared to 17 per cent in my data. This suggests that the Proética time frame, not reported in the documentation available to me, was in fact much longer than a year, even though yearly bribery rates are reported. I prefer my own survey to the TI and Proética surveys because of its large sample, wealth of covariates and additional questions on the bribery and usage of public officials.

\section{Which official types are most corrupt?}

Table 1 lists the twenty-one official types in order of their share of total bribery "episodes". A bribery episode is an encounter between a household (client) and official in which either a bribe was paid or a bribe was solicited by the official but the client refused to pay. Column 1 reports these shares, based on 91668 total encounters between households and officials and 1628

\footnotetext{
${ }^{7}$ Bertrand et al. (2005) analyze the use of agents for obtaining drivers' licenses in India.
} 
bribery episodes. The police account for 35 per cent of bribes and the city (municipal) government for 21 per cent, with the judiciary in third rank with 12 per cent. These three institutions account for 68 per cent of bribery episodes. Column 2 shows that these institutions are even more dominant in terms of total bribe payments: the judiciary alone accounts for 42 per cent of the money paid in bribes, followed by the police with 27 per cent and city government with 11 per cent, making a total of 80 per cent. The third column puts these shares in perspective by reporting the official type's share in household/official interactions: that is, the number of households using the official divided by the total over all official types. The police and judiciary represent only 2 per cent each of interactions with officials, while the city government has a higher 10 per cent share.

The data are sufficiently detailed that there could be many ways to combine them to produce a measure of how corruption varies by official type. Presumably corruption is some combination of the bribery rate and the average level of bribes paid. ${ }^{8}$ As a simple summary measure, I divide column 2 of Table 1, essentially the product of the rate and the amount, by column 3, the usage rate of various types of officials. The results are displayed in column 4 of Table 1 and in Figure 1.

By this measure, the judiciary is by far the most corrupt institution, with bribery levels twenty-six times the level that its usage rate would predict. The police force is also an outlier with about half the corruption of the judiciary. The next official type is "other", with one third the police corruption rate, but four times the next category. "Other" includes the Ministry of Transport and Communication, which houses the agency that grants drivers' licenses. Here the use of agents might be expected to lead to an underestimation of bribery. The "other" category

\footnotetext{
${ }^{8}$ Quid pro quos, not directly observable in the data, can also play a role. See Hunt (2004).
} 
also encompasses numerous small welfare programs as well as congress, the office of the president and the many unspecified ministries such as the Ministry of Energy and Mines. It is possible that corruption is high for this category because those who paid a bribe are more likely to remember having used an unspecified official type.

Corruption in other institutions is relatively modest compared to the top three although all these institutions carry out tasks that might lead to bribery. For example, the city government provides a variety of bribery-prone services such as construction and demolition permission, trash collection and title to property. Arbitration is to some extent a substitute for the judiciary. The Ministry of Agriculture provides title to agricultural land and credit to farmers. The Department of Migration provides visas for foreign workers and passports.

The election "office" in Table 1 is the Oficina Nacional de Processos Electorales (ONPE), while the election "court" is the Jurado Nacional de Elecciones (JNE). The election office (ONPE) runs elections, while the election court (JNE), which employs many lawyers, deals with electoral justice. The main reason for someone to use and bribe the election office (ONPE) would be to obtain a sticker confirming that he or she had participated in the mandatory voting (failure to obtain the sticker results in a suspension of legal rights). The election court (JNE) can issue exemptions and deals with any disputes over electoral outcomes or eligibility. Most activity connected with the national elections of April and June 2001 should be outside the twelve-month bribe windows of both the 2002 and 2003 surveys. However, there were municipal and regional elections on 17 November 2002, which would be inside the window for many 2002 and 2003 respondents.

The Ministry of Industry, Tourism, Integration and International Commercial Negotiation (MITINCI) issues permits for businesses, and the National Identification Registry issues identity 
documents and certificates of birth, marriage or divorce. The social security agency (ESSALUD) provides a wide variety of health-related services, such as clinics and hospitals, professional rehabilitation, health and disability insurance and worker's compensation. Reasons to bribe state hospitals (in principle distinct from those run by the social security agency) range from wanting to visit a patient outside visiting hours, to obtaining a certificate of health, to accessing the desired doctor. The main reason to bribe the water, electricity and telephone utilities is to speed up connections. The main reason to bribe state schools is to ensure registration of one's child at the appropriate school (the Parent-Teachers' Association typically collects this bribe). The development agency (FONCODES) could be bribed for a (typically agricultural) loan. State banks could be bribed to receive a loan or to be placed at the head of the long queue to pay the fine for not voting. Customs could be bribed to let goods enter or leave the country, and the tax authority in the same institution (SUNAT), known for its predatory ways, could be bribed not to do a tax audit, or possibly to lower tax liability. The food agency (PRONAA) could be bribed to judge that a family is eligible for food aid.

\section{Empirical strategy}

I analyze bribery rates and average bribe amounts in two steps. For bribery rates, I begin with the full data set of household/official pairs (21 officials times 36000 households), and extract those 91668 household/official pairs where the household used the official. I estimate the following probit regression for the probability of household $i$ having a bribery episode with official type $j$ :

$$
P\left(\text { Bribe }_{i j}\right)=\alpha_{1 j} \mu_{j}+X_{i} \beta_{1}+\beta_{2} Z_{i j}+\varepsilon_{i j} .
$$

The variables are defined as follows. The official type dummies are $\mu_{\mathrm{j}} ; Z_{\mathrm{ij}}$ represents the number of visits the household made to the official type (possibly for more than one purpose); and $\mathrm{X}_{\mathrm{i}}$ includes controls for the value of household consumption, respondent and household 
demographics, education, job type, student status, ownership of vehicles, location and time. The Appendix lists the covariates in detail, and discusses the computation of the standard errors.

The estimated coefficients $\hat{\alpha}_{1 \mathrm{j}}$ on the official type dummies $\mu_{\mathrm{j}}$ are the bribery rates adjusted for the characteristics of the clients. In a second step I use them as the dependent variable in a weighted least squares regression at the official type level:

$$
\hat{\alpha}_{1 \mathrm{j}}=\gamma+\phi \mathrm{O}_{\mathrm{j}}+\eta_{\mathrm{j}},
$$

where the $\mathrm{O}_{\mathrm{j}}$ are the characteristics of the officials. Because coefficients from non-linear regressions like the probit of equation 1 are difficult to interpret, when displaying the adjusted bribery rates graphically I most often present the marginal effects (the effect of increasing the covariate by one) instead.

I use as weights either the inverse of the squared standard errors of $\hat{\alpha}_{1 j}$ in the first stage (equation 1), or the share of the households that use the official type. The first set of weights reflects how precisely the coefficients were estimated in the first stage, but in practice these weights do not differ much across official types. ${ }^{9}$ The second set of weights reflects directly that bribery rates are measured with different precision by official type because of large differences in the number of clients using them.

I proceed similarly for the bribe amount. In the first stage I use the sample of 1628 household/official pairs where a bribe was paid and the amount specified, and run the OLS regression

$$
\log \left(\text { bribe amount }_{\mathrm{ij}}\right)=\alpha_{2 \mathrm{j}} \mu_{\mathrm{j}}+\mathrm{X}_{\mathrm{i}} \beta_{3}+\beta_{4} Z_{\mathrm{ij}}+v_{\mathrm{ij}} \text {, }
$$

\footnotetext{
${ }^{9}$ Borjas and Sueyoshi (1994) show that when the first stage is a probit, the weights necessary to recover the coefficients that would have obtained in a one step procedure are more complicated than the inverse of the squared standard errors. I show that the results are not sensitive to the weights.
} 
where $\mu_{j}, X_{i}$ and $Z_{i j}$ are as in equation 1 . The estimated coefficients $\hat{\alpha}_{2 j}$ on the official type dummies $\mu_{\mathrm{j}}$ are the adjusted bribe amounts, and in the second stage I use them as the dependent variable in a weighted least squares regression with the same form as equation 2 . The weights are either the inverse of the squared standard errors of the official type coefficients from the first stage or the number of reported bribe amounts for the official type.

I seek to capture in $\mathrm{O}_{\mathrm{j}}$ observable characteristics of officials representing factors identified as important in the introduction. Firstly, I compute an adjusted conclusion rate to represent the variation in service provision across official types net of client characteristics and behavior. This is designed to capture queues, red tape and other reasons for slow or ineffectual service that are unrelated to bribery. Respondents are asked whether their business with the official type was concluded (“concluyó”). As in English, the Spanish is ambiguous as to whether conclusion implies successful conclusion. The one word question "concluyó?" is beside the column where the number of visits to the official is recorded, and both are under the heading asking how many times the respondents went to the official (in the previous twelve months). In this context, it is likely that the respondents interpreted the question about conclusion as a question as to whether they were still in the process of dealing with the official. ${ }^{10}$ The mean across households is 93 per cent, with the means by official type ranging from 54 per cent for the judiciary and 72 per cent for the Ministry of Agriculture to 98 per cent for state schools (see column 5 of Table 1).

\footnotetext{
${ }^{10} \mathrm{I}$ assume without evidence that respondents forced to pay off police officers to avoid fines for imaginary offences also interpret the question as asking whether they are still engaged in dealings with the officer.
} 
I run a probit with the same covariates as for equation 1, excluding the number of visits $Z_{\mathrm{ij}}$, where the dependent variable is whether the client $i$ concluded her business with the official $j$ :

$$
\mathrm{P}\left(\text { Concluded business }_{\mathrm{ij}}\right)=\alpha_{3 \mathrm{j}} \mu_{\mathrm{j}}+\mathrm{X}_{\mathrm{i}} \beta_{5}+\xi_{\mathrm{ij}}
$$

Because the conclusion of business is influenced by bribery behavior, I run this regression on a sample of household/official pairs where there was no bribery episode. I refer to the estimated coefficients $\hat{\alpha}_{3 j}$ on the official type dummies as the adjusted conclusion rate, and use them as one of the covariates in $\mathrm{O}_{\mathrm{j}}$.

I assume that neither the average bribery rate nor the average amount paid for the official type belongs in equation 4 (that is, that they are not among the official characteristics being captured by the official type dummies $\mu_{\mathrm{j}}$ ). This is important: if speed at which officials conclude business honestly is affected by how many of their colleagues are taking bribes and/or how much they are taking in bribes, the adjusted conclusion rate will be endogenous in equation 2 . For example, if corruption demoralizes honest officials or otherwise reduces effort in honest dealings, the coefficient on the adjusted conclusion rate in equation 2 will be biased downward, and any beneficial effect of fast conclusion overstated. A related point is that the sample includes some clients who did not notice that their slow service indicated the official was angling for a bribe. If dishonest and honest officials differ in ability, the adjusted conclusion rate would also not measure the conclusion rate that would obtain if all officials behaved honestly. Finally, if some respondents perceive the question about conclusion to mean successful conclusion, and if some of these respondents judge success based on whether the official was willing to perform an illegal act for the client, a high conclusion rate is not unambiguously a good thing. 
The second variable I include in $\mathrm{O}_{\mathrm{j}}$ is the response rate to the question on the amount of the bribe paid. This functions as a selection correction, in case those who did not report the amount were disproportionately those who paid large bribes, and in case officials whose clients were loath to report the amount of the bribe had clients who also underreported bribing at all. The response rate over all clients is 98 per cent, but is much lower for the food agency compared to any other official type: 50 per cent, compared to 86 per cent for the official type with the next lowest response rate.

A third set of variables included in $\mathrm{O}_{\mathrm{j}}$ is the means of client characteristics by official type. Because the impact of individual client characteristics has already been incorporated, these means represent the indirect effects of other clients' characteristics. For example, if official scruples are endogenous and are weakened in the face of temptation, a client may be more likely to have to bribe if the other clients are rich. Alternatively, if the other clients are rich, the institution will attract less scrupulous officials, increasing the bribery rate for all clients. I experimented unsuccessfully with a proxy for a fourth characteristic of officials: the value of the benefit the official has in his power (how much is at stake).

If a higher conclusion rate reduces bribery by reducing the number of clients disgruntled with the service, the correct specification for equation 2 is slightly different. In this case, $\mathrm{O}_{\mathrm{j}}$ should include a measure of client satisfaction, which should be instrumented by the conclusion rate. The coefficient on the satisfaction variable would then reflect the effect on bribery of a change in satisfaction caused by a change in the conclusion rate.

Such a measure of satisfaction is available: respondents are asked to rate the quality of service as good, medium or bad. Thirty-four per cent of clients rate their service as good; nine per cent as bad. As shown in column 6 of Table 1, the share of clients rating the service as bad 
ranges from 38 per cent for the police to 4 per cent for state schools. I create, by official type, an adjusted share of clients reporting bad service, using an adjustment procedure identical to that used for the conclusion rate. $\mathrm{I}$ include this variable in $\mathrm{O}_{\mathrm{j}}$ and instrument it with the adjusted conclusion rate. To test for robustness, I alternatively instrument with the adjusted share of clients who reported seeing the official immediately, and replace the share of clients reporting bad service with the share reporting good service.

\section{Raw and adjusted bribery rates and average bribe amounts}

Figure 2 indicates the raw bribery episode rates by official type and the associated 95 per cent confidence intervals, with the vertical line at 0.048 giving the city government rate as a reference point. Thirty-seven per cent of those using the police and 17 per cent of those using the judiciary had a bribery episode; bribery at the telephone and electric authorities was negligible.

Figure 3 shows the adjusted bribery rates (marginal effects, with the city government coefficient normalized to zero) and the associated confidence intervals. The adjustment reduces the confidence intervals (the scales are different in the two figures) and explains much of the difference between the very corrupt officials and the others, but does not change the ranking of the officials much. Figure 4 makes clearer that a large amount of the variance across official types is explained by client characteristics. It plots the raw and adjusted bribery rates on the same figure (with the city government bribery rate subtracted from the raw rates). The unweighted standard deviation of the 21 raw bribery rates is 0.084 , while the unweighted standard deviation of the 21 adjusted bribery rates is 0.032 , so two-thirds of the standard deviation, or 85 per cent of the variance, is explained by household characteristics. Client characteristics explain most of the (statistically significant) difference in the bribery rate between the judiciary and city government and more than half the difference between the police and city government. The adjusted judiciary 
and police bribery rates remain significantly higher than that of city government, however. The adjustment brings the lower bribery group, from the election office on down, slightly closer to the city government, although the gap remains statistically significant. ${ }^{11}$

I repeat this exercise for the bribe amount in Figures 5-7. The large confidence intervals of Figure 5, which reports raw means of log bribe amounts, reflect the small number of reported bribe amounts for some types of official. The highest "mean" is for the election court, where in fact only one bribe amount (of 80 Nuevo soles, or about US \$24) is reported; the second ranked institution, the Ministry of Industry, also has only one bribe amount reported. The judiciary, which by contrast has many bribes and a tight confidence interval, is in third rank, closely followed by "other", arbitration, social security and the police. ${ }^{12}$ The difference between the judiciary and the police is statistically significant, but many other gaps are not.

Of the 2.1 per cent of bribes that are 500 Nuevo soles or more (US \$150), 47 per cent went to the judiciary; of the 1.2 per cent of bribes (19 bribes) that are 1000 Nuevo soles or more (US \$300), 53 per cent went to the judiciary. The highest reported bribe is 15000 Nuevo soles (about US\$4500), to the judiciary, compared to bribes of between $\$ 2500$ and $\$ 10,000$ paid by Montesinos to ordinary judges (McMillan and Zoido 2004).

The adjusted bribe amounts in Figure 6 have tighter confidence intervals and have some small ranking differences compared to the raw bribe means in Figure 5. However, as Figure 7 makes clear, the adjustment scarcely affects the size of the gaps between the official types (the unweighted variance of 0.67 actually rises to 0.71 ). Although bribery rates vary across official

\footnotetext{
${ }^{11}$ Haisken-DeNew and Schmidt (1997) discuss subtleties associated with measuring the variance of the coefficients on such group effects.

12 The ranking of average bribes, rather than average log bribes, is different: judiciary (mean 260 Nuevo soles, or US \$78), other (144), election court (80), arbitration (72), police (50), Ministry of Industry (50).
} 
types in large part because client profiles vary across official types, the variance in the size of bribes paid across official types is almost unrelated to these different profiles, and must instead be almost fully determined by differences in the institutions themselves.

Given these results, one can understand why the plots marked with circles in Figure 8 show little relation between the official types with high raw bribery rates and the official types with high raw average bribe amounts. The plots marked with crosses show that there is also no correlation between the adjusted rates and the adjusted bribe amounts.

\section{Determinants of adjusted bribery rates and adjusted bribe amounts}

Figure 9 plots the adjusted bribery rate (coefficients now, rather than marginal effects as in earlier graphs) against the adjusted rate of concluding business with officials, and the unweighted regression line connecting them. The fit is very good, with only the police rather far from the regression line: the police have a higher bribery rate than would be expected given their rate of concluding business. This might be the result of the latitude enjoyed by police officers to seek out their own clients and impose a fine if a bribe is not forthcoming (inspectors of various kinds also have this latitude): such actions are intimately associated with bribery but are often concluded on the spot. Alternatively, clients of the police may have fewer (unobservable) scruples.

The first column of Table 2 shows that in the regression with weights based on the standard errors from the first (household/official) stage, the adjusted business conclusion rate alone explains 46 per cent of the variance in the bribery rate, and has a t-statistic of -4.0. In column 2 I add the response rate for the bribe amount, which is insignificant and does not affect the coefficient on the conclusion rate. To make the coefficients easy to interpret, I rerun the regression of column 2 performing all adjustments to obtain the dependent and independent 
variables using OLS, rather than using any probits. The resulting coefficient on the adjusted conclusion rate, in column 3 , indicates that a 10 percentage point increase in this rate (the unweighted standard deviation) reduces the adjusted bribery rate by 3.8 percentage points, a very large effect.

The first three columns suggest that when conclusion rates are low, clients get frustrated and bribe. To check that dissatisfaction with service is indeed the correct mechanism, I control for the adjusted share of clients saying service was bad, instead of the adjusted conclusion rate, in column 4, and instrument it with the adjusted conclusion rate in column 5. In both columns, the coefficient on bad service is positive and significant, as expected, with a larger absolute value than the conclusion coefficient of columns 1 and 2. In column 6 I repeat column 5 with different weights, the share of households using the official type, which reduces the coefficient on the bad service variable.

To help interpret the coefficients, in column 7 I rerun the column 6 regression making adjustments using OLS only. The coefficient of 0.76 indicates that a 10 percentage point increase in the share of clients who think the service is bad increases the bribery rate by 7.6 percentage points. We can use the coefficient on the conclusion rate in the first stage of the IV regression, -0.65 (lower panel of column 7), to relate this coefficient to the direct coefficient on the conclusion rate in column $3(-0.38)$. A 10 percentage point increase in the conclusion rate reduces the share of clients rating service as bad by 6.5 percentage points, which in turn reduces bribery by $0.76 * 6.5=4.9$ percentage points, similar to the 3.8 percentage point effect of column 3. The results are very similar when the first set of weights (from columns 1-5) is used.

The next step is to add to the covariates the third component of $\mathrm{O}_{\mathrm{j}}$ : average characteristics of clients, particularly the value of household consumption and the share of clients 
in various types of job such as white collar and self-employed in agriculture (see the Appendix). Household consumption has a significant positive coefficient if the job categories are included, but not otherwise. Certain job category coefficients are significant, but only if household consumption is included. These unreported results are somewhat difficult to interpret. They might imply indirect or spillover effects between clients or indicate that unscrupulous officials gravitate to institutions with bribe-prone clients.

The corresponding regressions for the adjusted log bribe amounts are presented in Table 3; Figure 10 graphs the adjusted bribe amount against the adjusted conclusion rate (showing coefficients, not marginal effects). Columns 1 and 2 and the figure show that the adjusted business conclusion rate is significantly negatively related to the log bribe amount when the official types are weighted similarly (in the table) or equally (the regression line of the figure). The fit is not as good as in the case of the bribery rates, however, with only 20 per cent of the variance in the bribe amount explained. In column 2, as in later columns, the response rate for the bribe amount has an insignificant coefficient. The fully linear version of column 2, presented in column 3 , indicates that a 10 percentage point increase in the conclusion rate reduces the bribe amount by $38 \log$ points or 32 percent, a large effect.

In columns 4 and 5 I control for the share of clients reporting bad service, rather than the conclusion rate. This variable has an insignificant coefficient when not instrumented, but a positive coefficient significant at the 10 per cent level when instrumented in column 5 . The coefficient becomes smaller but much more significant when the weights are the number of bribe amounts reported, in column 6: the increased significance comes from the low weight on the observations from the Figure 10 regression line owing to their being based on a tiny number of bribes. 
The fully linear results of column 7 indicate that a 10 percentage point increase in the share of clients reporting bad service reduces the bribe amount by a statistically significant 58.9 $\log$ points (45 per cent), and the unadjusted R-squared rises to 0.43 . Because the first stage coefficient on the conclusion rate is -0.60 (column 7 lower panel), this means that a 10 percentage point increase in the conclusion rate reduces the bribe amount by $0.60 * 58.9=35 \log$ points, or 30 per cent. This is very similar to the direct effect of $38 \log$ points in column 3 .

As was the case for the bribery rate, average client household consumption is a significant determinant of the bribe amount only if the share of clients in various job categories are included, and vice versa. When all these covariates are included, the significant coefficients have opposite signs from the bribery rate regression (these results are not reported). More research is needed to characterize indirect or spillover effects between clients.

I have repeated the instrumental variables regressions of Tables 2 and 3 using the share of clients reporting good, rather than bad, service. The conclusion rate has a larger and much more significant effect on the number of clients judging service to be bad than on the number judging service to be good. Thus, the impact of the conclusion rate on bribery works not through creating happy clients, but rather through reducing the number of unhappy clients. Unreported regressions also indicate that using as an instrument the adjusted share of clients who saw the official immediately works well (and predicts bad service better than good service) and gives similar results to Tables 2 and 3. Allowing clients to see the official immediately is a good first step in speeding up the conclusion rate, increasing client satisfaction and lowering bribery.

\section{Conclusion}

Peruvian data on bribery rates and on household bribe payments indicate that almost all the variance in bribery rates across types of officials can be explained by client characteristics and 
by the share of cases that officials acting honestly are able to conclude (adjusted for client characteristics). A ten percentage point increase in the adjusted conclusion rate (a standard deviation) reduces the bribery rate net of client characteristics by $4-5$ percentage points. By contrast, the bribe amounts paid to different official types are unaffected by client characteristics and are uncorrelated with the bribery rates. However, a ten percentage point rise in the adjusted conclusion rate reduces the average amount of the bribe by $30-32$ per cent. The effect of the conclusion rate is causal if the conclusion rate of officials acting honestly is independent of the degree of corruption of their colleagues.

Although it is inevitable that different types of officials serve client pools that differ in their propensity to bribe, the results indicate that speeding up clients' dealings with officials would be very helpful in reducing bribery rates and amounts. The rate at which officials conclude cases should be easier to monitor than bribery itself, but care must be taken to avoid a decline in service quality. Cutting red tape, providing more resources and improving administrative efficiency should all help.

I find some evidence that the characteristics of the official's other clients help to explain a given client's bribery behavior. However, the results differ qualitatively depending on whether one considers the bribery rate or bribe amount, and are difficult to interpret. I therefore draw no firm conclusions concerning indirect or spillover effects, or the concentration of unscrupulous officials in institutions with bribe-prone clients. I speculate that both for the bribe amount and bribery rates, the stakes and the degree of internal competition play a role in explaining the remaining variance.

The judiciary is by far the most corrupt institution in Peru, with both a high bribery rate and a high value of bribes, and it has by far the lowest conclusion rate. Only 54 per cent of 
clients concluded their business with the judiciary within the 12 month window of the survey. The magnitude of the effects uncovered suggests considerable scope for reducing the bribery rate by speeding up Peru's infamously slow judicial proceedings. This will require a sustained investment in attracting and training more lawyers and judges and providing these judges with permanent contracts. Faster proceedings would also help reduce the high value of the bribes paid to the judiciary, but the inevitably high stakes, low internal competition and unwilling participation of defendants associated with judicial proceedings may be significant obstacles to progress.

The police are also highly corrupt in Peru: although the value of bribes paid is not much above average, the bribery rate is the highest of any official type, at 37 per cent. The police have a much higher bribery rate than their conclusion rate warrants. This suggests that other, possibly more difficult to implement reforms, must supplement an increase in the conclusion rate. A peculiarity of the police -- that they can extort bribes from clients of their choosing, may well explain this, and should be a target of policy. The police may also deal with clients with fewer scruples than average, something that policy cannot influence. 


\section{Data and Regression Appendix}

The 2002 survey contains information from interviews in October-December 2002. The "2003" survey contains information from interviews in every month from May 2003 to April 2004. I have made no adjustments for inflation nor for seasonality consumption patterns, and simply use the total value of household consumption as computed by the statistical office. The statistical office imputes some components of consumption where necessary. Two thousand of the 18000 addresses interviewed in 2002 were re-interviewed in the 2003 survey.

Regressions at the household/official level to adjust the bribery rate and bribe amount include: the number of visits to the official type, seven regional dummies, household size dummies, town size dummies, dummies for interview months from May 2003-April 2004, time to the district administrative center; "job type" dummies for the respondent's main job -- employer (nonagricultural), employer (agricultural), self-employed (non-agricultural), self-employed (agricultural), white collar, domestic worker, unpaid family member, other and not employed (the omitted type is laborer); characteristics of the respondent -- sex, married/cohabiting, married/cohabiting*sex, age and age squared, student status, whether main job is in public administration; characteristics of the household -- number of earners, number of members in school, ownership dummies for bicycle, car/van, tricycle, motorbike and truck, whether land obtained by invasion, presence of children aged 0-3, 4-7, 8-11 and 12-15 and whether any member other than the respondent had each of the several job types.

The regressions used to adjust the probability of concluding business with the official, the perceived quality of service and the probability of seeing an official immediately contain the same covariates, excluding the number of visits, but the sample contains only respondents who did not experience a bribery episode. The standard errors in all regressions at the household/official level are clustered by district, allowing for correlation of the errors across residents of the same district in any survey period. This procedure takes into account that people in the same district might have similar behaviors, and that in fact panel households appear twice in the sample. 


\section{References}

Ades, Albert and Rafael Di Tella (1997), "National Champions and Corruption: Some Unpleasant Interventionist Arithmetic”, Economic Journal, 107 (443), 1023-1042.

Bardhan, Pranab (1997), "Corruption and Development: A Review of Issues", Journal of Economic Literature, 35 (3), 1320-1346.

Bertrand, Marianne, Simeon Djankov, Rema Henna and Sendhil Mullainathan (2005), "Obtaining a Driving License in India: An Experimental Approach to Studying Corruption”, MIT Working Paper.

Borjas, George and Glenn Sueyoshi (1994), "A Two-Stage Estimator for Probit Models with Structural Group Effects”, Journal of Econometrics, 64 (1), 165-182.

Fisman, Raymond and Roberta Gatti (2002), "Decentralization and corruption: evidence across countries", Journal of Public Economics, 83, 325-345.

Haisken-DeNew, John and Christoph Schmidt (1997), "Interindustry and Interregion Differentials: Mechanics and Interpretation", Review of Economics and Statistics, 79 (3), $516-521$.

Hunt, Jennifer (2004), "Trust and Bribery: The Role of the Quid Pro Quo and the Link with Crime", NBER Working Paper 10510, May.

Hunt, Jennifer and Sonia Laszlo (2005), "Bribery: Who Pays, Who Refuses, What Are The Payoffs?", McGill University working paper.

Lui, Francis (1985), “An Equilibrium Queuing Model of Bribery”, Journal of Political Economy, 93 (4), $760-781$.

McMillan, John and Pablo Zoido (2004), "How to Subvert Democracy: Montesinos in Peru", Journal of Economic Perspectives, 18 (4), 69-92.

Mocan, Naci (2004), "What Determines Corruption? International Evidence from Micro Data", NBER Working Paper 10460, April.

Proética - Consorcio Nacional Para La Ética Pública (2004), “Opinión Pública: Tercera Encuesta Nacional Sobre Corrupción”, Lima: APOYO Opinión Y Mercado.

Proética - Consorcio Nacional Para La Ética Pública (2003), “Opinión Pública: Segunda Encuesta Nacional Sobre Corrupción”, Lima: APOYO Opinión Y Mercado.

van Rijckeghem, Caroline and Beatrice Weder (2001), "Bureaucratic corruption and the rate of temptation: do wages in the civil service affect corruption, and by how much?", Journal of Development Economics, 65, 307-331. 
Rose-Ackerman, Susan (1978), Corruption: A Study in Political Economy, New York: Academic Press.

Rose-Ackerman, Susan (1999), Corruption and Government: Causes, Consequences, and Reform, Cambridge: Cambridge University Press.

Shleifer, Andrei and Robert Vishny (1993), "Corrruption", Quarterly Journal of Economics, 108 (3), 599-618.

Svensson, Jakob (2003), "Who Must Pay Bribes and How Much? Evidence from a Cross-Section of Firms", Quarterly Journal of Economics, 68 (1), 207-230.

Swamy, Anand, Stephen Knack, Young Lee and Omar Azfar (2001), "Gender and Corruption”, Journal of Development Economics, 64, 25-55.

Transparency International (2001), "Country Report on the National Integrity System in Peru", Lima: APOYO/Transparency International.

Transparency International (2004), "Report on the Transparency International Global Corruption Barometer 2004", www.transparency.org/surveys/index.html\#barometer, accessed 21 May 2005.

Treisman, Daniel (2000), "The causes of corruption: a cross-national study", Journal of Public Economics, 76 (3), 399-457.

U.S. Department of State (2005), "2005 Investment Climate Statement - Peru", www.state.gov/e/eb/ifd/2005/43037.htm, accessed 16 May 2005. 
Table 1: Shares of Bribes, Bribe Payments and Sample by Official Type

\begin{tabular}{|c|c|c|c|c|c|c|}
\hline & $\begin{array}{c}\text { (1) } \\
\text { Share of } \\
\text { bribery } \\
\text { episodes }\end{array}$ & $\begin{array}{c}(2) \\
\text { Share of } \\
\text { amount } \\
\text { of bribe } \\
\text { payments }\end{array}$ & $\begin{array}{c}(3) \\
\text { Share of } \\
\text { household- } \\
\text { official } \\
\text { interactions }\end{array}$ & $\begin{array}{c}(4) \\
\text { Corruption } \\
\text { index } \\
(2) /(3)\end{array}$ & $\begin{array}{c}\text { (5) } \\
\text { Business } \\
\text { conclusion } \\
\text { rate }\end{array}$ & $\begin{array}{c}(6) \\
\text { Clients } \\
\text { reporting } \\
\text { bad } \\
\text { service }\end{array}$ \\
\hline Police & 0.35 & 0.27 & 0.02 & 12.7 & 0.81 & 0.38 \\
\hline City government & 0.21 & 0.11 & 0.10 & 1.1 & 0.90 & 0.13 \\
\hline Judiciary & 0.12 & 0.42 & 0.02 & 26.3 & 0.54 & 0.36 \\
\hline State schools & 0.08 & 0.05 & 0.21 & 0.2 & 0.98 & 0.04 \\
\hline State hospitals & 0.04 & 0.02 & 0.13 & 0.2 & 0.93 & 0.10 \\
\hline National ID registry & 0.04 & 0.02 & 0.06 & 0.3 & 0.88 & 0.11 \\
\hline Water & 0.03 & 0.01 & 0.12 & 0.1 & 0.95 & 0.09 \\
\hline Other & 0.03 & 0.05 & 0.01 & 3.9 & 0.78 & 0.21 \\
\hline $\begin{array}{l}\text { Ministry of } \\
\text { Agriculture }\end{array}$ & 0.02 & 0.01 & 0.01 & 1.1 & 0.72 & 0.15 \\
\hline State banks & 0.02 & 0.004 & 0.06 & 0.06 & 0.95 & 0.07 \\
\hline Social security & 0.02 & 0.01 & 0.03 & 0.3 & 0.88 & 0.16 \\
\hline Electricity & 0.02 & 0.003 & 0.14 & 0.02 & 0.96 & 0.05 \\
\hline $\begin{array}{l}\text { Department of } \\
\text { Migration }\end{array}$ & 0.01 & 0.003 & 0.004 & 0.9 & 0.91 & 0.11 \\
\hline Customs and taxes & & & 0.02 & 0.05 & 0.92 & 0.07 \\
\hline Election office & & & 0.004 & 0.6 & 0.86 & 0.10 \\
\hline Telephone & Less & Less than & 0.04 & 0.001 & 0.95 & 0.09 \\
\hline $\begin{array}{l}\text { Development } \\
\text { agency }\end{array}$ & $\begin{array}{c}\text { than } 1 \% \\
\text { each }\end{array}$ & $1 \%$ each & Less than & 0.5 & 0.76 & 0.11 \\
\hline Arbitration & & & $1 \%$ each & 1.0 & 0.87 & 0.10 \\
\hline Election court & & & & 0.4 & 0.90 & 0.07 \\
\hline Food agency & & & & 0.02 & 0.81 & 0.16 \\
\hline Ministry of Industry & & & & 0.4 & 0.83 & 0.10 \\
\hline All & 1 & 1 & 1 & 1 & 0.93 & 0.09 \\
\hline Observations & 2123 & 1628 & 91668 & -- & 91668 & 91668 \\
\hline
\end{tabular}

Notes: Bribery episodes include cases where the client refused to bribe (463). A number of bribe payers do not report the amount of the bribe (32). The Ministry of Industry is an abbreviation for the Ministry of Industry, Tourism, Integration and International Commercial Negotiation. 
Table 2: Determinants of Adjusted Bribery Rates by Official Type

(T-statistics in parentheses)

\begin{tabular}{|c|c|c|c|c|c|c|c|}
\hline & (1) & (2) & (3) & (4) & (5) & (6) & (7) \\
\hline $\begin{array}{l}\text { Business conclusion } \\
\text { rate (adjusted) }\end{array}$ & $\begin{array}{l}-0.98 \\
(-4.0)\end{array}$ & $\begin{array}{l}-1.00 \\
(-4.1)\end{array}$ & $\begin{array}{l}-0.38 \\
(-2.5)\end{array}$ & -- & -- & -- & -- \\
\hline $\begin{array}{l}\text { Share clients saying } \\
\text { service bad } \\
\text { (adjusted) }\end{array}$ & -- & -- & -- & $\begin{array}{l}1.58 \\
(5.1)\end{array}$ & $\begin{array}{l}1.70 \\
(4.6)\end{array}$ & $\begin{array}{l}1.12 \\
(3.2)\end{array}$ & $\begin{array}{l}0.76 \\
(3.1)\end{array}$ \\
\hline $\begin{array}{l}\text { Response rate for } \\
\text { bribe amount }\end{array}$ & -- & $\begin{array}{l}1.41 \\
(1.3)\end{array}$ & $\begin{array}{l}0.12 \\
(0.9)\end{array}$ & $\begin{array}{l}1.42 \\
(1.4)\end{array}$ & $\begin{array}{l}1.45 \\
(1.5)\end{array}$ & $\begin{array}{l}1.81 \\
(0.8)\end{array}$ & $\begin{array}{l}0.06 \\
(0.3)\end{array}$ \\
\hline R-squared & 0.46 & 0.50 & 0.27 & 0.60 & 0.60 & 0.41 & 0.48 \\
\hline Adjusted R-squared & 0.43 & 0.45 & 0.19 & 0.56 & 0.55 & 0.35 & 0.42 \\
\hline $\begin{array}{l}\text { Instrumental } \\
\text { variables }\end{array}$ & -- & -- & -- & -- & Yes & Yes & Yes \\
\hline $\begin{array}{l}\text { Adjusted conclusion } \\
\text { rate (in first stage) }\end{array}$ & -- & -- & -- & -- & $\begin{array}{l}-0.59 \\
(-6.6)\end{array}$ & $\begin{array}{c}-0.71 \\
(-11.1)\end{array}$ & $\begin{array}{l}-0.65 \\
(-8.3)\end{array}$ \\
\hline $\begin{array}{l}\text { All adjustments } \\
\text { made using OLS }\end{array}$ & -- & -- & Yes & -- & -- & -- & Yes \\
\hline Weights & \multicolumn{5}{|c|}{$\begin{array}{l}\text { Reciprocal of squared standard errors from } \\
\text { household-official level regression }\end{array}$} & \multicolumn{2}{|c|}{$\begin{array}{l}\text { Share of households } \\
\text { using official }\end{array}$} \\
\hline
\end{tabular}

Notes: Weighted regressions on 21 observations. The dependent variable in columns 1-5 is the set of coefficients on the official type dummies in a probit for the probability of paying a bribe. The adjusted business conclusion rate is the set of coefficients on official type dummies from a probit for the probability of concluding business with the official. The adjusted share of clients reporting bad service is the set of coefficients on official type dummies from a probit for the probability of experiencing bad service with the official. For columns 3 and 7 all adjustments to variables are made using OLS. Where instrumental variables is performed, the adjusted share of clients reporting bad service has been instrumented with the adjusted business conclusion rate. 
Table 3: Determinants of Adjusted Bribe Amounts by Official Type (T-statistics in parentheses)

\begin{tabular}{|c|c|c|c|c|c|c|c|}
\hline & (1) & (2) & (3) & (4) & (5) & (6) & (7) \\
\hline $\begin{array}{l}\text { Business } \\
\text { conclusion rate } \\
\text { (adjusted) }\end{array}$ & $\begin{array}{l}-0.85 \\
(-2.1)\end{array}$ & $\begin{array}{l}-0.90 \\
(-2.3)\end{array}$ & $\begin{array}{l}-3.83 \\
(-2.1)\end{array}$ & -- & -- & -- & -- \\
\hline $\begin{array}{l}\text { Share clients saying } \\
\text { service bad } \\
\text { (adjusted) }\end{array}$ & -- & --- & -- & $\begin{array}{c}0.46 \\
(0.8)\end{array}$ & $\begin{array}{l}1.58 \\
(1.9)\end{array}$ & $\begin{array}{l}1.09 \\
(4.2)\end{array}$ & $\begin{array}{l}5.89 \\
(4.9)\end{array}$ \\
\hline $\begin{array}{l}\text { Response rate for } \\
\text { bribe amount }\end{array}$ & -- & $\begin{array}{l}2.56 \\
(1.5)\end{array}$ & $\begin{array}{l}2.50 \\
(1.5)\end{array}$ & $\begin{array}{l}2.42 \\
(1.3)\end{array}$ & $\begin{array}{l}2.84 \\
(1.4)\end{array}$ & $\begin{array}{c}-3.1 \\
(-0.8)\end{array}$ & $\begin{array}{l}-2.63 \\
(-0.7)\end{array}$ \\
\hline R-squared & 0.20 & 0.29 & 0.26 & 0.10 & -- & 0.36 & 0.43 \\
\hline Adjusted R-squared & 0.15 & 0.21 & 0.18 & 0.00 & -- & 0.29 & 0.36 \\
\hline $\begin{array}{l}\text { Instrumental } \\
\text { variables }\end{array}$ & -- & -- & -- & -- & Yes & Yes & Yes \\
\hline $\begin{array}{l}\text { Adjusted } \\
\text { conclusion rate (in } \\
\text { first stage) }\end{array}$ & -- & -- & -- & -- & $\begin{array}{l}-0.57 \\
(-5.8)\end{array}$ & $\begin{array}{l}-0.68 \\
(-9.6)\end{array}$ & $\begin{array}{l}-0.60 \\
(-6.9)\end{array}$ \\
\hline $\begin{array}{l}\text { All adjustments } \\
\text { made using OLS }\end{array}$ & -- & -- & Yes & -- & -- & -- & Yes \\
\hline Weights & \multicolumn{5}{|c|}{$\begin{array}{l}\text { Reciprocal of squared standard errors from } \\
\text { household-official level regression }\end{array}$} & \multicolumn{2}{|c|}{$\begin{array}{l}\text { Number of bribe } \\
\text { amounts reported }\end{array}$} \\
\hline
\end{tabular}

Notes: Weighted regressions on 20 observations. The dependent variable in columns 1-5 is the set of coefficients on the official type dummies in an OLS regression for the $(\log )$ amount of the bribe. The adjusted business conclusion rate is the set of coefficients on official type dummies from a probit for the probability of concluding business with the official. The adjusted share of clients reporting bad service is the set of coefficients on official type dummies from a probit for the probability of experiencing bad service with the official. For columns 6 all adjustments to variables are made using OLS. Where instrumental variables is performed, the adjusted share of clients reporting bad service has been instrumented with the adjusted business conclusion rate. 
Figure 1: Corruption Ranking of Official Types

City government Min of Agriculture Arbitration Dept of Migration Election office Development agency Election court Min of Industry etc

Social security

ID registry State schools State hospitals Water

State banks Customs and taxes Electricity Food agency Telephone

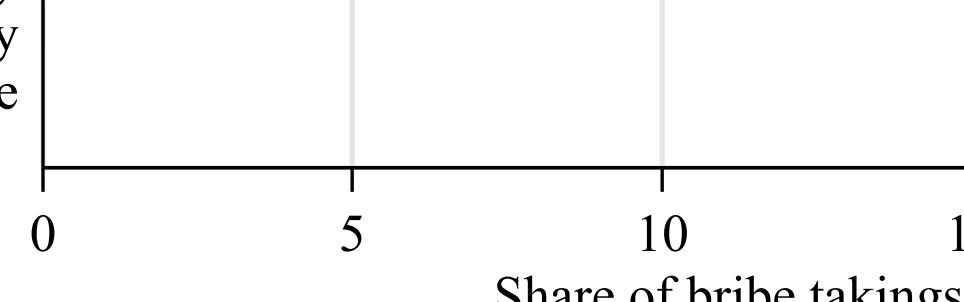

5

20

Share of bribe takings/share of usage 
Figure 2: Bribery Episode Rate by Official Type

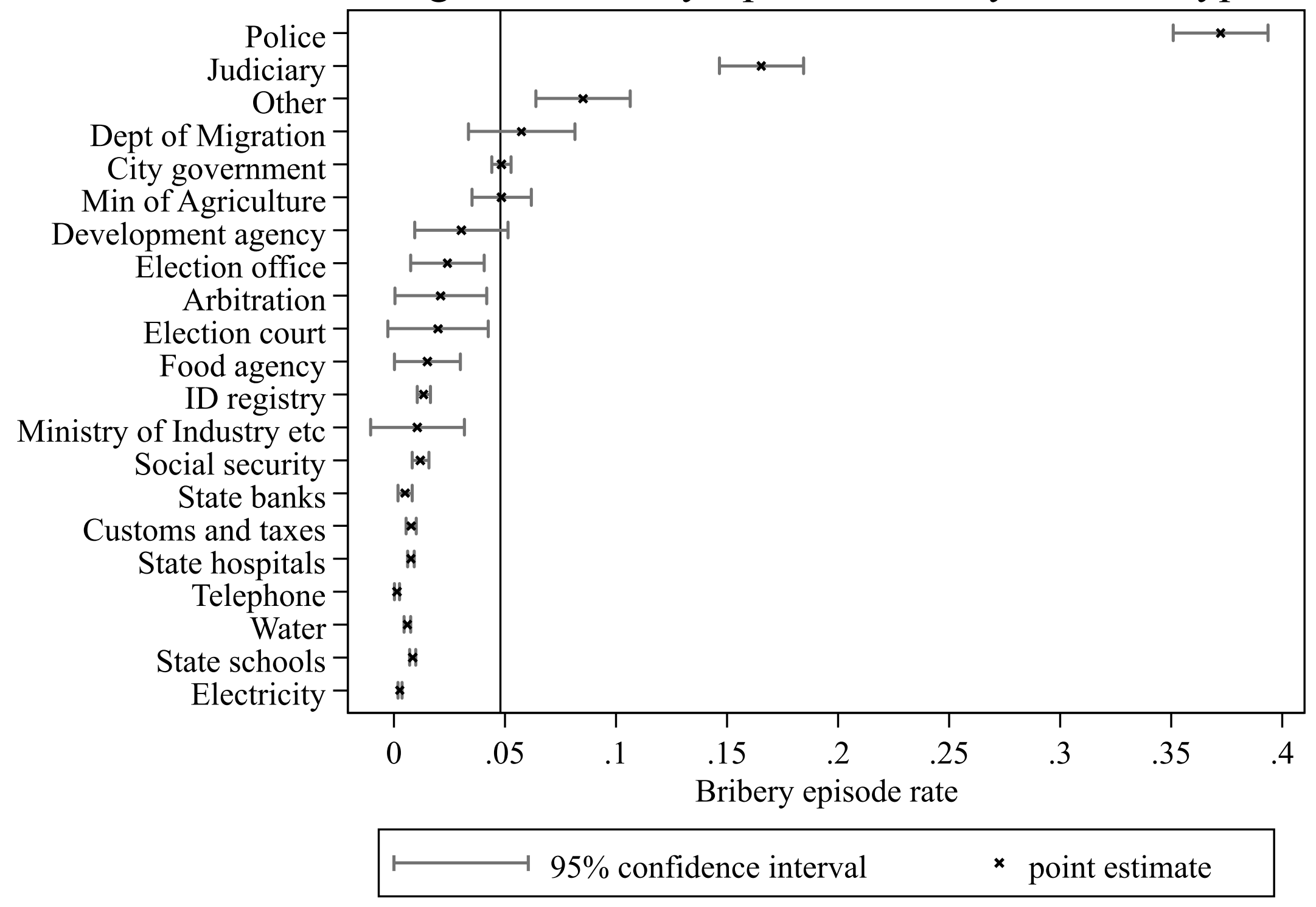


Figure 3: Adjusted Bribery Rate by Official Type

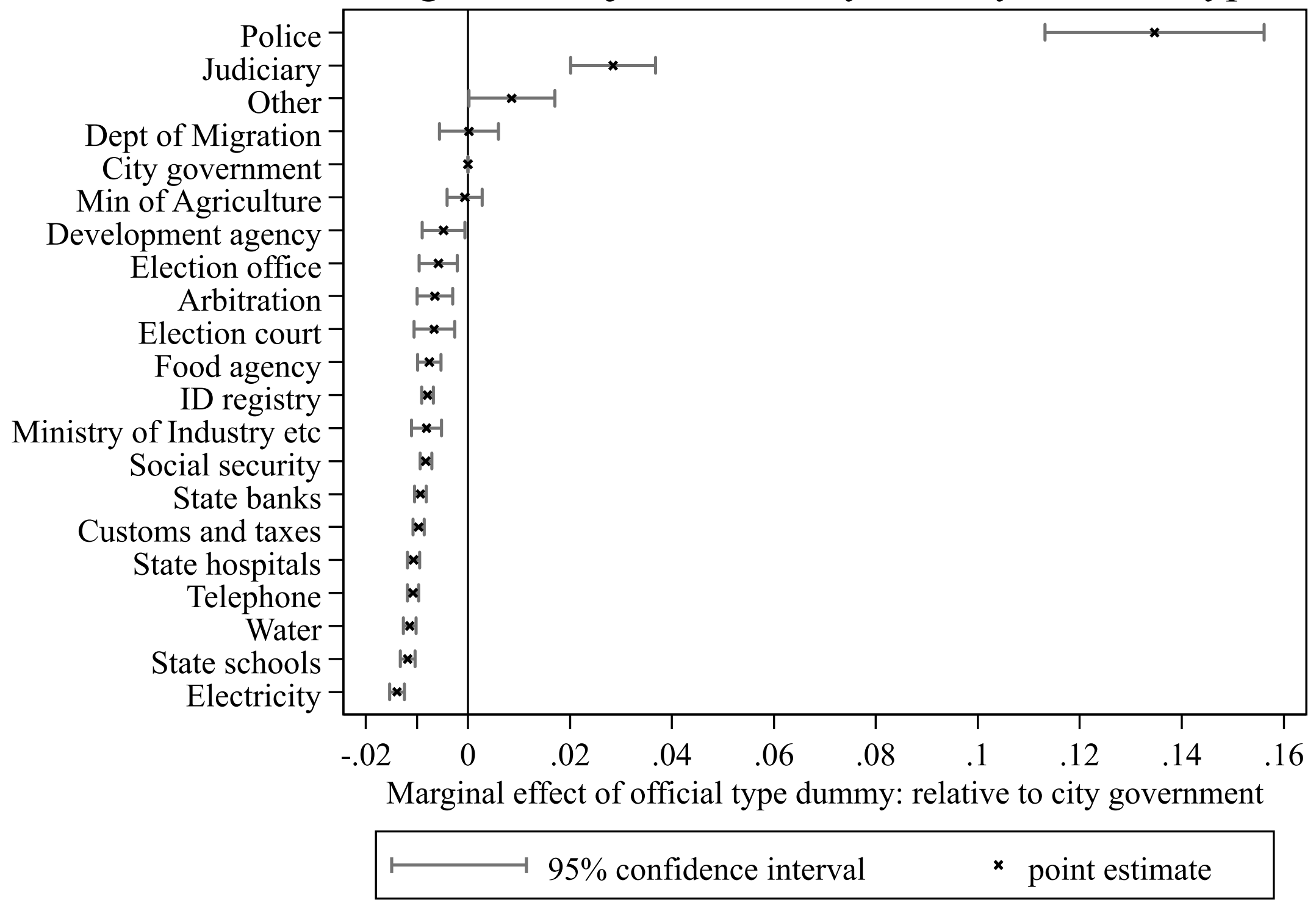


Figure 4: Adjusted and Unadjusted Bribery Rates

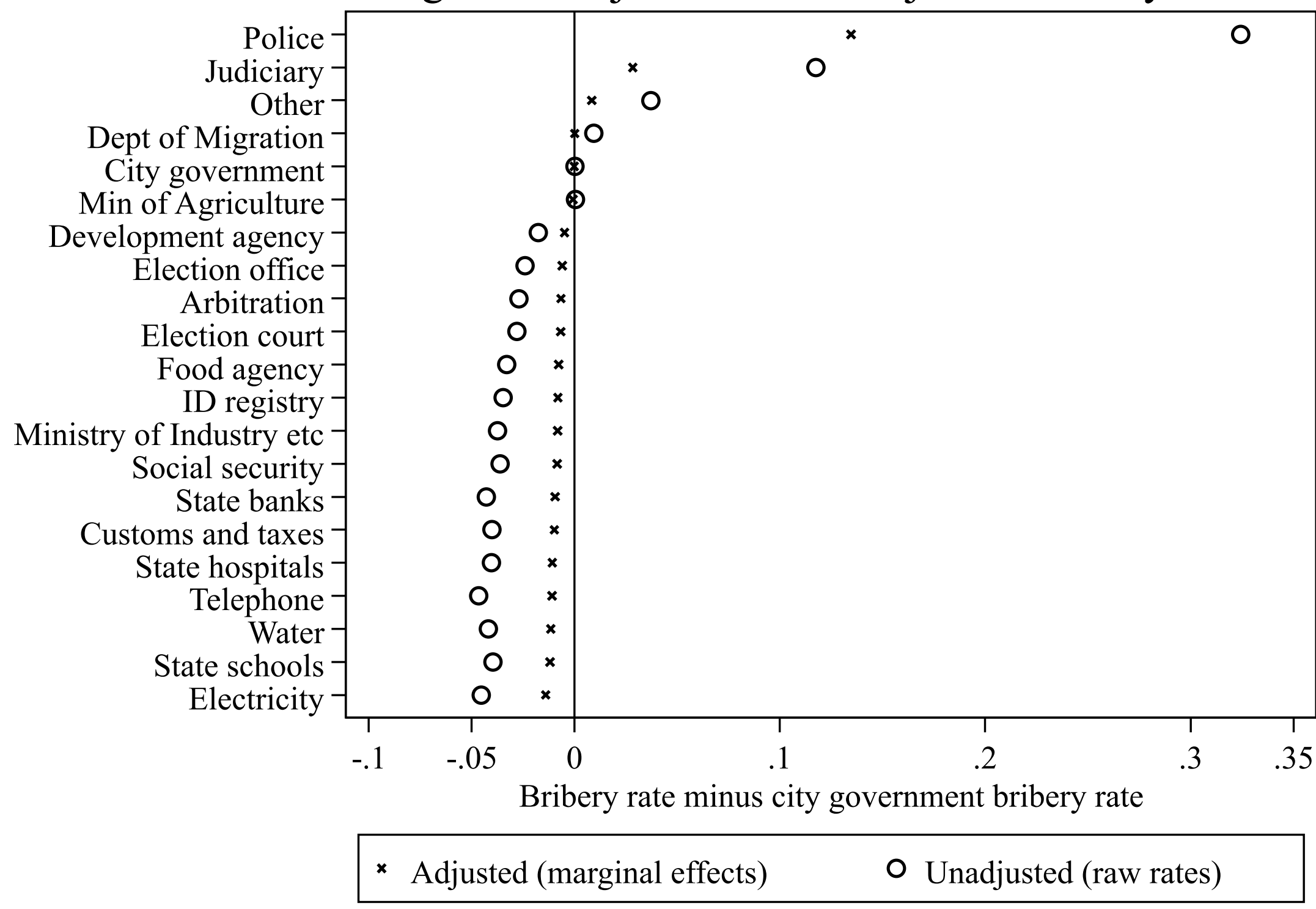


Figure 5: Average Bribe Amount by Official Type

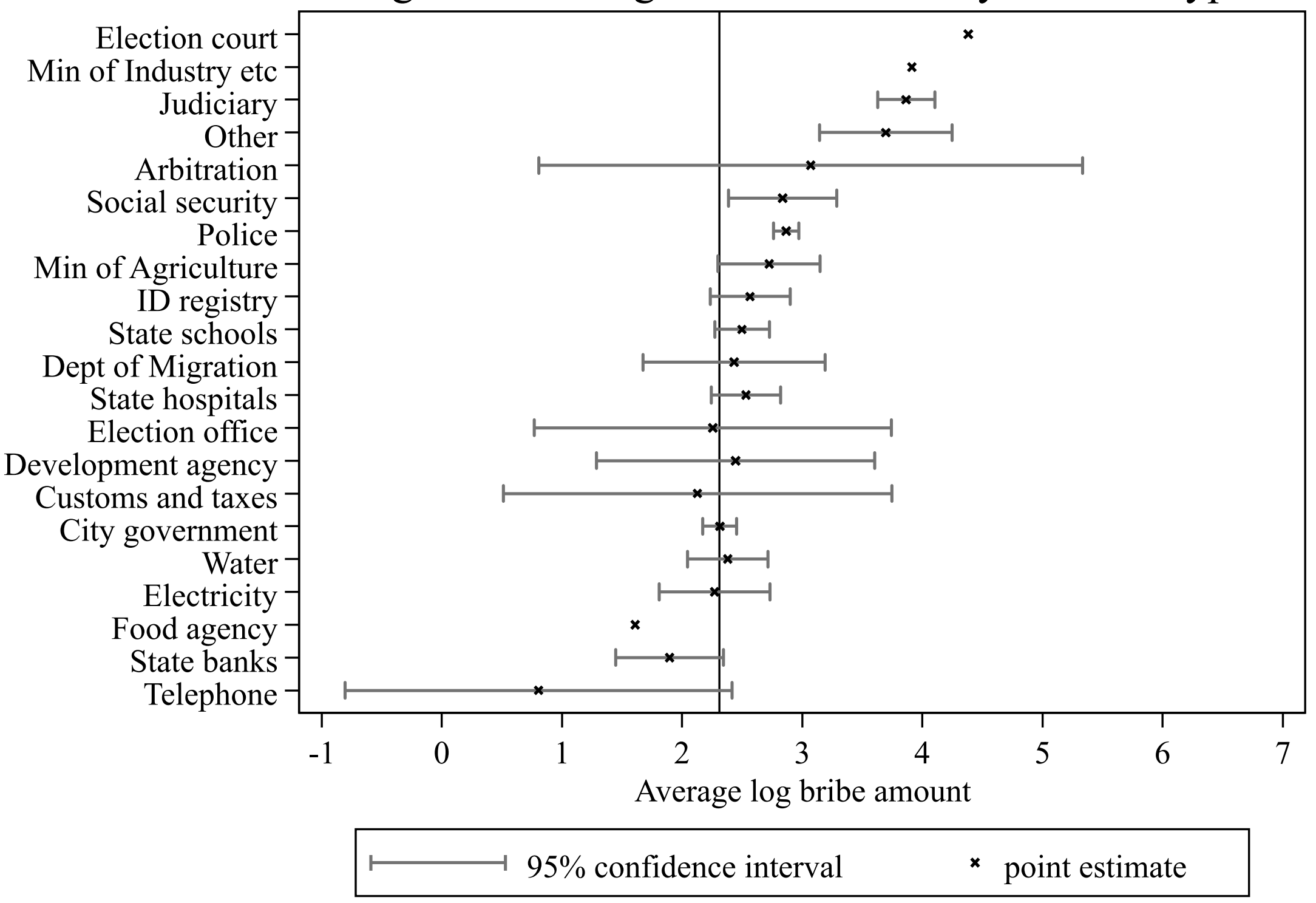


Figure 6: Adjusted Bribe Amount by Official Type

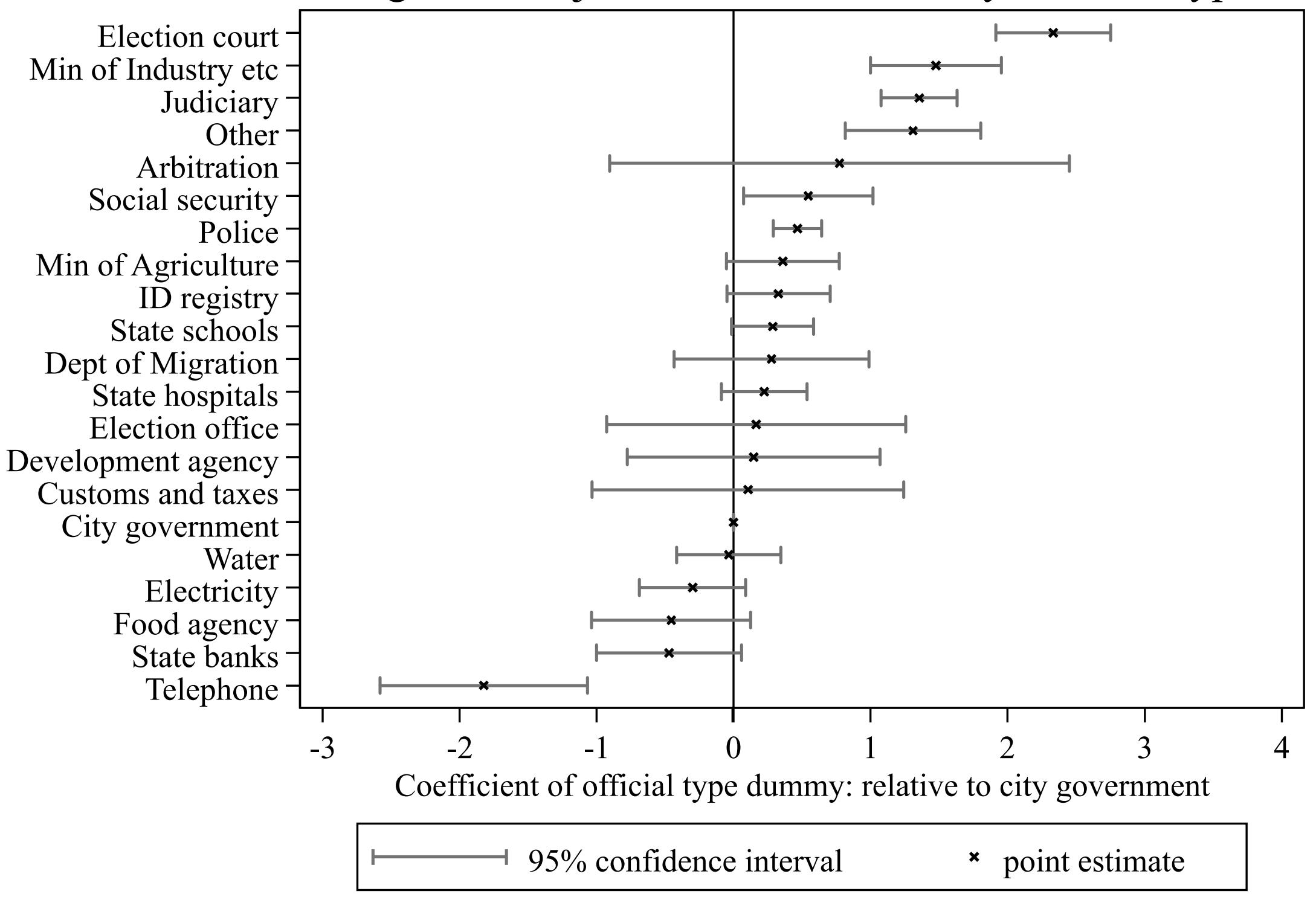


Figure 7: Adjusted and Unadjusted Bribe Amounts

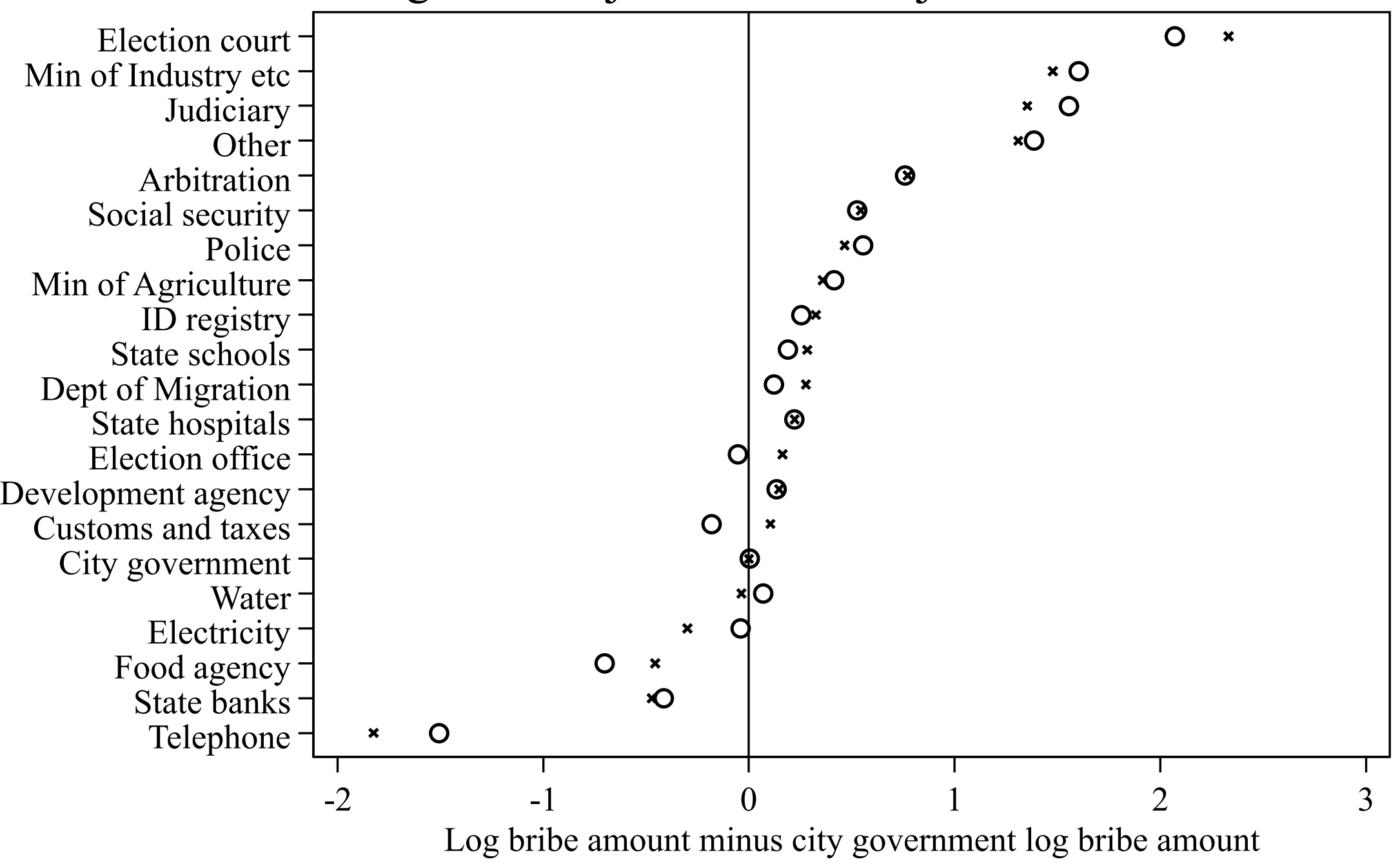

\begin{tabular}{|ll|}
\hline × Adjusted (coefficients) & O Unadjusted (raw means) \\
\hline
\end{tabular}


Figure 8: Adjusted Bribery Rate versus Adjusted Bribe Amount

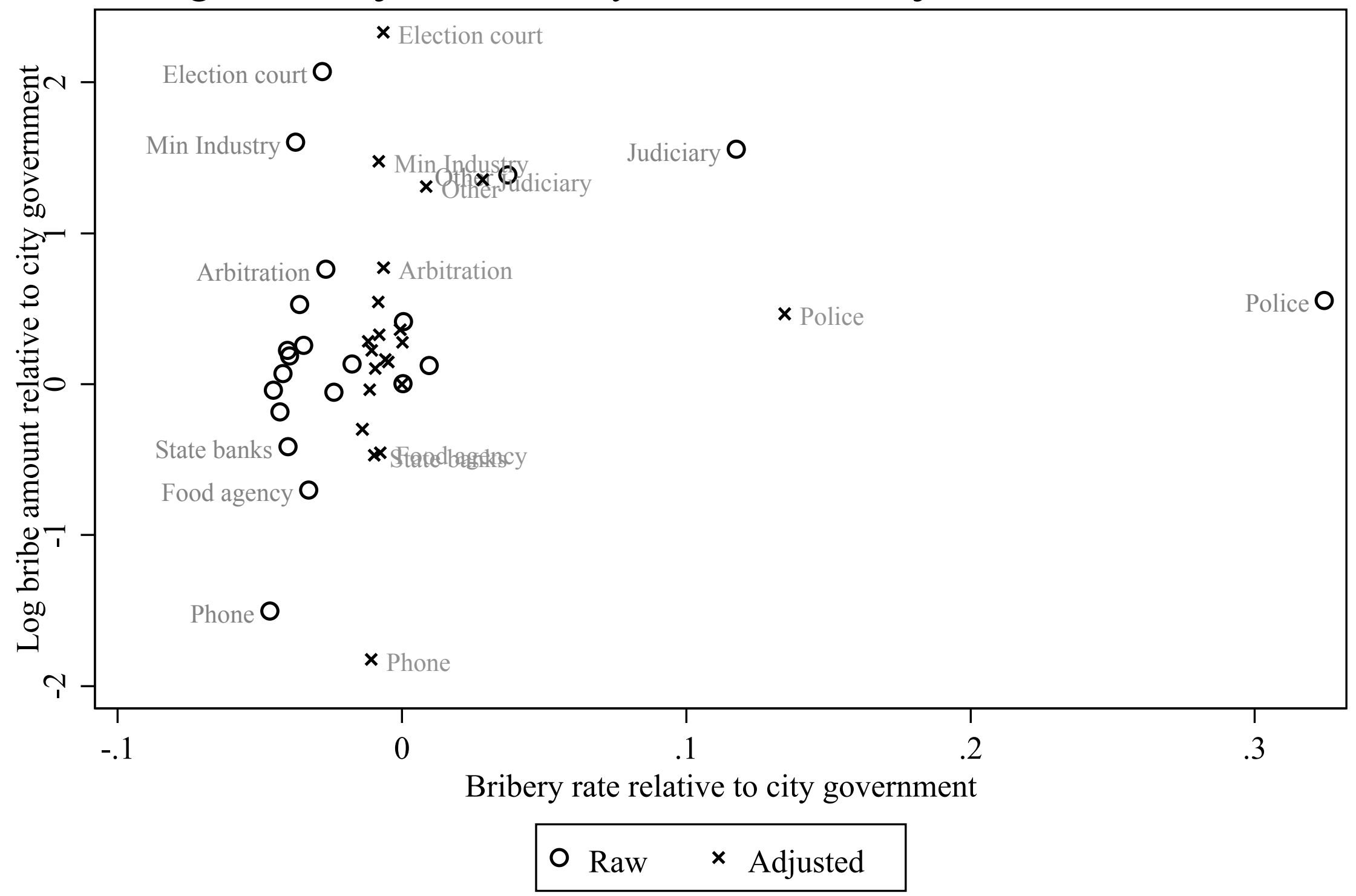


Figure 9: Adjusted Bribery Rate versus Adjusted Conclusion Rate

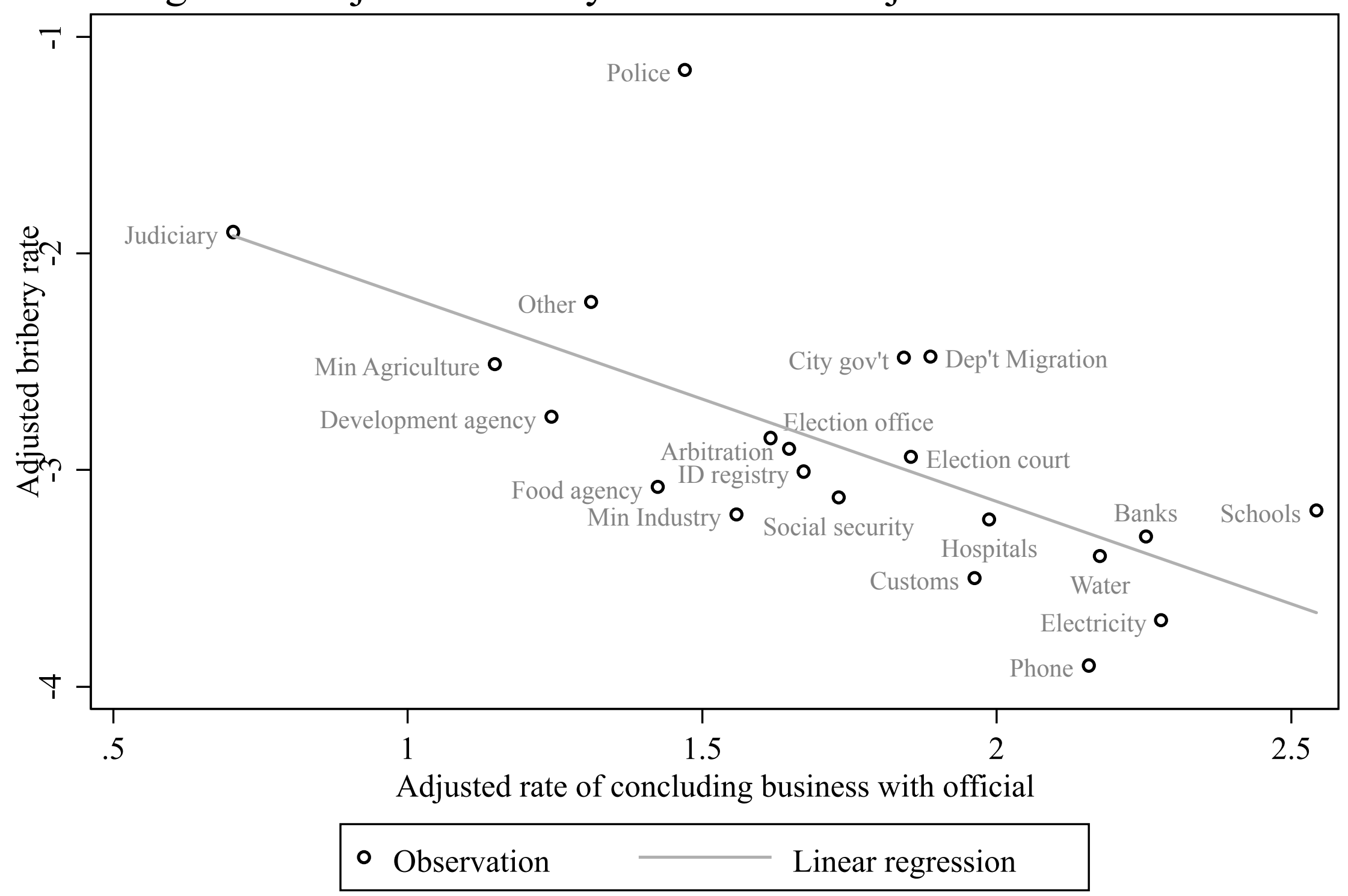


Figure 10: Adjusted Bribe Amount versus Adjusted Conclusion Rate

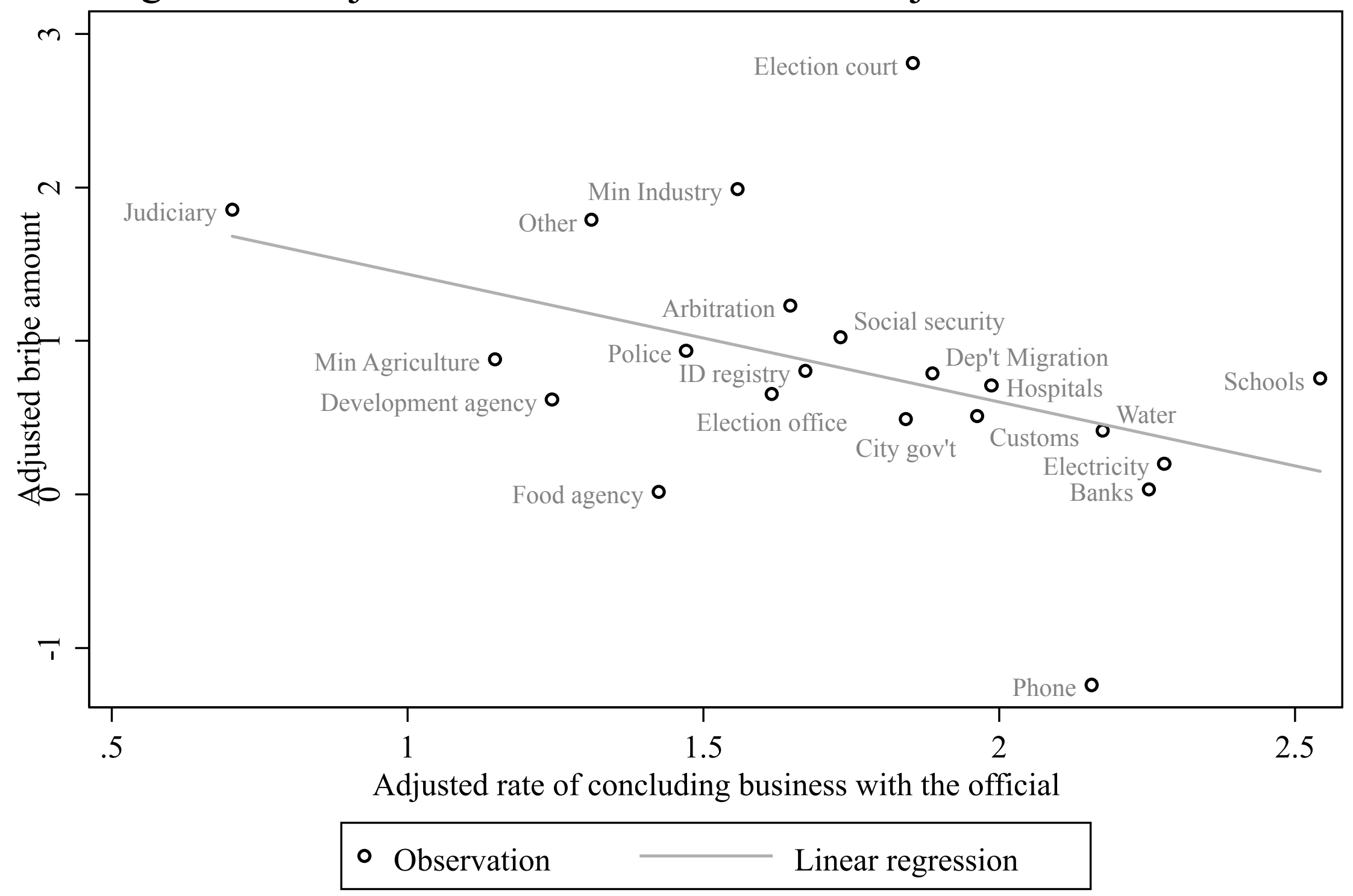

